\title{
A hasonló fokú fiziológiás és patológiás balkamra-hipertrófia különbözö in vivo hemodinamikai következményekhez vezet
}

\author{
Oláh Attila*, Sayour Alex Ali, Németh Balázs Tamás, Mátyás Csaba, \\ Hidi László, Lux Árpád, Ruppert Mihály, Kellermayer Dalma, Szabó Lilla, \\ Török Marianna, Meltzer Anna, Gellér László, Merkely Béla, Radovits Tamás
}

\author{
Semmelweis Egyetem, Városmajori Szív- és Érgyógyászati Klinika, Kísérleti Kutatólaboratórium, Budapest \\ Levelezési cím: Dr. Oláh Attila PhD, kardiológus szakorvosjelölt, Kísérleti Kutatólaboratórium, SE, Városmajori Szív- és \\ Érgyógyászati Klinika, 1122 Budapest, Városmajor u.68., e-mail: o.attilio@gmail.com
}

Célkitűzés: A balkamra (BK)-hipertrófia a szívizom válasza a megnövekedett terhelésre, amely lehet fiziológiás (FH) vagy patológiás $(\mathrm{PH})$ természetű. $E$ két állapot funkcionális következményeinek direkt összehasonlításáról még nem született tanulmány. Célunk az FH és PH kisállat-modelljeinek részletes összehasonlító hemodinamikai jellemzése BK-i nyomás-térfogat (P-V) analízis segítségével.

Módszerek: Patkányainkban FH kialakulását úszóedzéssel (sportszív), PH-t a hasi aorta műtéti szűkítésével (aortic banding, $A B$ ) idéztük elö. A szív morfológiai változásait echokardiográfiával követtük. A szívműködés részletes jellemzésére BK-i P-V analízist végeztünk. In vivo méréseinket hisztológiai és molekuláris biológiai módszerekkel egészítettük ki. Adatainkat az adott modell kontrollcsoportjára normalizáltuk.

Eredmények: Szívultrahanggal hasonló mértékủ hipertrófia volt kimutatható fiziológiás és patológiás hipertrófiában. Az AB-állatoknál fokozott szubendokardiális fibrózis volt jellemző, míg sportszívben fibrotikus átépülést nem találtunk a myocardiumban. A fötális génprogram reaktiválódása csak PH-ban volt megfigyelhető. FH-ban magasabb verőtérfogatot találtunk, ezzel szemben $\mathrm{PH}-$ ban emelkedett végszisztolés nyomás mellett változatlan verőtérfogatot mértünk. A diasztolés funkciót jellemző aktív relaxáció javult sportszívben, azonban nagyfokú romlást mutatott az AB-állatoknál. Az érzékeny BK-i kontraktilitás-indexek mindkét csoportban a hipertrófiával arányosan emelkedtek. Míg a BK mechanikus hatásfoka FH-ban javult, PH-ban változatlan maradt. A mitokondriális markerek génexpressziója csökkent PH-ban.

Következtetések: Munkánkkal elsőként adtunk részletes funkcionális összehasonlítást a fiziológiás és patológiás BK-hipertrófia állatmodelljeiben. Mindkét típusú hipertrófiában fokozódik a szívizom kontraktilitása. A karakterisztikus különbségek a diasztolés funkcióban és a BK mechanoenergetikai állapotában mutatkoznak, amelynek hátterében mitokondriális különbségek állhatnak.

Kulcsszavak: fiziológiás hipertrófia, patológiás hipertrófia, nyomás-térfogat analízis, mitokondriális markerek

Physiological and pathological left ventricular hypertrophy of comparable degree is associated with characteristic differences of in vivo hemodynamics

Purpose: Left ventricular (LV) hypertrophy is a physiological or pathological response of LV myocardium to increased cardiac load. We aimed at investigating and comparing hemodynamic alterations in well-established rat models of physiological hypertrophy $(\mathrm{PhyH})$ and pathological hypertrophy $(\mathrm{PaH})$ by using LV pressure-volume $(\mathrm{P}-\mathrm{V})$ analysis.

Methods: $\mathrm{PhyH}$ and $\mathrm{PaH}$ were induced in rats by swim training and by abdominal aortic banding, respectively. Morphology of the heart was investigated by echocardiography. Characterization of cardiac function was completed by LV P-V analysis. In addition, histological and molecular biological measurements were performed.

Results: Echocardiography revealed myocardial hypertrophy of similar degree in both models, which was confirmed by post-mortem heart weight data. In aortic-banded rats we detected subendocardial fibrosis. Reactivation of fetal gene program could be observed only in the $\mathrm{PaH}$ model. PhyH was associated with increased stroke volume, whereas unaltered stroke volume was detected in $\mathrm{PaH}$ along with markedly elevated end-systolic pressure values. Sensitive indexes of LV contractility were increased in both models, in parallel with the degree of hypertrophy. Active relaxation was ameliorated in athlete's heart, whereas it showed marked impairment in $\mathrm{PaH}$. Mechanical efficiency and ventriculo-arterial coupling were improved in PhyH, whereas they remained unchanged in $\mathrm{PaH}$. Myocardial gene expression of mitochondrial regulators showed marked differences between $\mathrm{PaH}$ and $\mathrm{PhyH}$. Conclusions: We provided the first comparative hemodynamic characterization of $\mathrm{PhyH}$ and $\mathrm{PaH}$ in relevant rodent models. Increased LV contractility could be observed in both types of LV hypertrophy; characteristic distinction was detected in diastolic function (active relaxation) and mechanoenergetics (mechanical efficiency), which might be explained by mitochondrial differences. Keywords: physiological hypertrophy, pathological hypertrophy, pressure-volume analysis, mitochondrial markers 


\section{Bevezetés}

Szívizom-hipertrófia alatt a szívizomsejtek megnövekedéséből adódó szívtömeg-gyarapodást értjük, amely a szívet érő megemelkedett terhelésre adott válasz során fejlődik ki. A patológiás és fiziológiás szívizom-hipertrófiát eltérő fiziológiás és patológiás ingerek alakíthatják ki, amelyek különböző strukturális és molekuláris fenotípussal társulnak (1).

Amennyiben a nyomás- vagy térfogat-túlterhelést betegség váltja ki (pl. magas vérnyomás, billentyűbetegség), patológiás szívizom-hipertrófia alakul ki, amely kezdetben a megnövekedett biomechanikai stresszt kompenzáló jelenségnek tekinthető és a kardiovaszkuláris funkció fenntartását célozza kóros körülmények között (2). A patológiás hipertrófia cardiomyocyta veszteséggel (apoptózis, nekrózis), intersticiális fibrózissal, és a fötális génprogram reaktivációjával jár $(1,3)$. Ezen állapot előrehaladása idővel szisztolés és diasztolés miokardiális diszfunkcióhoz (szívelégtelenséghez) vezet. A szívelégtelenség incidenciája folyamatosan növekszik az idősödő társadalmakban, amely a leggyakoribb halálokok egyike. Ezen nagyméretű egészségügyi probléma számos kutatást inspirált, amelyek újfajta gyógyszeres támadáspont azonosítását célozták annak érdekében, hogy megelőzhető vagy visszafordítható legyen a patológiás szívizom-hipertrófia kialakulása (4).

A hosszú távú fizikai edzés szintén a szívizom megnagyobbodásával jár, amelyet sportszív néven illetnek. A patológiás hipertrófiával ellentétben ezen kiegyensúlyozott miokardiális tömegnövekedés javult szívfunkcióval társul kötőszövetes átalakulás, cardiomyocyta apoptózis és a fötális génprogram változása nélkül (2, 3). Emellett a testedzés protektív hatása a kardiovaszkuláris prevenció és terápia tekintetében széles körben elismertté vált $(5,6)$. A fiziológiás hipertrófiát közvetítő intracelluláris szignálutak pontos ismerete potenciális támadáspontot biztosíthat a patológiás hipertrófia és a szívelégtelenség terápiájában (7).

A morfológiai hasonlósága ellenére a patológiás és fiziológiás szívizom-hipertrófia kialakulásában lényegesen eltérő jelátviteli útvonalak játszanak szerepet, amelyhez jelentősen különböző gén- és fehérjeexpressziós jelleg társul (1, 8, 9). Bár számos tanulmány vizsgálta ezen molekuláris eltéréseket, a kétfajta szívmegnagyobbodás közötti funkcionális különbségek kevésbé feltártak. Mindezidáig a fiziológiás és patológiás balkamra (BK) -hipertrófia noninvazív módszerekkel történő összehasonlításáról rendelkezünk ismerettel kísérleti állatokon $(2,10)$ és embereken $(11,12)$. Ezen kutatások a BK-i funkció számos aspektusát vizsgálták ezen két hipertrófia típusban, azonban a noninvazív módon mért paraméterek függenek a terhelési körülményektől, így ezen vizsgálatok nem elég részletesek ahhoz, hogy pontosan megértsük a szívizomzat mechanikájának eltéréseit.
A nyomás-térfogat $(P-V)$ analízis a jelenleg ismert legátfogóbb technika a szív in vivo szisztolés és diasztolés funkciójának, továbbá mechanoenergetikai jellegzetességeinek meghatározásában, amely módszerrel nyert hemodinamikai paraméterek kevésbé függenek a kamrai elő- és utóterheléstől, valamint a szívfrekvenciától (13).

Jelen tanulmányunkban célul tüztük ki, hogy részletes hemodinamikai összehasonlítást adjunk az edzéssel (fiziológiás), illetve nyomás-túlterheléssel (patológiás) kiváltott BK-hipertrófia esetén, BK-i P-V analízis segítségével két széles körben használt patkánymodellen és vizsgáljuk a különbségek hátterében meghúzódó molekuláris eltéréseket.

\section{Anyagok és módszerek}

\section{Állatok, kísérleti csoportok}

Vizsgálatainkat a kísérleti állatok tartásáról és felhasználásáról szóló nemzetközi szabályoknak (EU Directive 2010/63/EU; Guide for the Care and Use of Laboratory Animals, US National Institutes of Health 2011) megfelelően végeztük. Fiatal felnőtt, hím Wistar patkányainkat (m=200-250 g; Toxi-Coop, Dunakeszi, Magyarország) standard körülmények között, konstans $22 \pm 2{ }^{\circ} \mathrm{C}$ hőmérsékleten, 12 h fény/sötétség ciklusokban tartottuk. Az állatok testtömegét (BW) rendszeresen kontrolláltuk.

\section{Úszóedzés: fiziológiás szívizom-hipertrófia modell}

Sportoló patkányainkat (Ex, n=12) fokozatos hozzászoktatás után 12 héten keresztül, heti öt napon át, napi 200 percen át úsztattuk, ahogy azt korábban bemutattuk (14). A kontrollcsoport (Co, n=11) a heti öt alkalom mindegyikén 5 percet töltött a vízben, a vízzel való érintkezés okozta stressz esetleges hatásainak kiküszöbölésére.

\section{Hasi aortaszúkítés: nyomás-indukálta patológiás szívizom-hipertrófia modell} A hasi aorta szűkítésével $(A B, n=10)$ a bal kamra fokozott utóterhelését váltottuk ki. A mütéti beavatkozásokat a korábban leírt módon végeztük el (15). Röviden pentobarbitál anesztéziát követően a hasi aorta felkeresése után a suprarenalis szakasz elülső falához egy 0,9 mm külső átmérőjű 20 G-s tompa hegyű tűt helyeztünk. Az aorta keresztmetszetét 2-0 sebészi fonál alkalmazásával a tű méretére szükítettük. A tủ óvatos eltávolításával kapott ligatúrák így a bal kamra hasonló mértékben növekedett utóterhelését hozták létre az állatokban. $A z$ áloperált (Sham, $n=8$ ) állatok hasonló mútéti eljáráson estek át a hasi aorta szűkítése nélkül, így kontrollként szolgáltak. Ezt követően az állatokat 6 héten keresztül megfigyeltük.

\section{Echokardiográfia}

Az állatokat ip. pentobarbitál (60 mg/ttkg) injekcióval elaltattuk, majd egy füthető műtőasztal segítségé- 
vel testhőmérsékletüket állandóan tartottuk $\left(37^{\circ} \mathrm{C}\right)$. Transztorakális szívultrahangos vizsgálatot végeztünk, amely során kétdimenziós hossz- és keresztmetszeti, valamint M-mód felvételeket készítettünk egy $13 \mathrm{MHz}-$ es lineáris ultrahangfej (GE 12L-RS, GE Healthcare, USA) segítségével. Egy képelemző szoftver segítségével (EchoPac, GE Healthcare, USA) a rögzített felvételeken anterior (AWT), poszterior (PWT) és szeptális (IVST) falvastagságot szisztoléban (index: s) és diasztoléban (index: d), valamint BK-i végdiasztolés és végszisztolés átmérőt (LVEDD, illetve LVESD) és areákat mértünk, majd ezekből morfológiai és funkcionális paramétereket számítottunk: frakcionális rövidülést (FS), végdiasztolés (LVEDV) és végszisztolés (LVESV) térfogatokat, ejekciós frakciót (EF). A bal kamrai szívizomtömeget (LV-mass) a korábban leírt módon számoltuk, majd ezt az értéket a poszt-mortem mért tibiahosszra normalizáltuk (LV-mass index).

\section{Hemodinamikai mérések:}

\section{bal kamrai P-V-analízis}

A kísérleti protokoll végéhez érve a patkányokat ip. pentobarbitál (60 mg/ttkg) injekcióval elaltattuk, tracheotomia és intubáció után mesterségesen lélegeztettük, testhőmérsékletüket a kísérlet során $37^{\circ} \mathrm{C}$-on tartottuk. A jobb oldali arteria carotis communis felöl egy 2Fr-es nyomás-konduktancia mikrokatétert (SPR-838, Millar Instruments, USA) vezettünk a felszálló aortába, ahol stabilizáció után artériás középnyomást (MAP) mértünk. A katétert a bal kamrába továbbvezetve regisztráltuk a bal kamrai nyomás- és térfogatviszonyokat és kiszámítottuk a következő hemodinamikai paramétereket: bal kamrai végszisztolés nyomás (LVESP), bal kamrai végdiasztolés nyomás (LVEDP), BK-i szisztolés nyomásnövekedés maximális sebessége $\left(\mathrm{dP}_{\mathrm{d}} \mathrm{dt}_{\max }\right), \mathrm{BK}$-i diasztolés nyomáscsökkenés maximális sebessége $\left(\mathrm{dP}_{\mathrm{d}} \mathrm{dt}_{\min }\right), \mathrm{BK}-\mathrm{i}$ relaxáció időkonstansa $(\mathrm{T})$, BK-i végdiasztolés térfogat (LVEDV), BK-i végszisztolés térfogat (LVESV), SV, EF, perctérfogat $(\mathrm{CO})$, szívindex $(\mathrm{Cl}=\mathrm{CO} / \mathrm{BW})$, verőmunka (SW) és teljes perifériás ellenállást (TPR=MAP/CO). A volumenértékek meghatározását a korábban leírt kalibráció segítségével végeztük (16).

A vena cava inferior kompressziója mellett regisztrált bal kamrai nyomás-térfogat-összefüggések segítségével érzékeny, elő- és utóterheléstől független balkamrai kontraktilitás-indexeket számítottunk: a végszisztolés nyomás-térfogat-összefüggés meredekségét (ESPVR), a verőmunka - végdiasztolés térfogat összefüggés meredekségét (az ún. preload recruitable stroke work, PRSW) és a dP/dt $\mathrm{max}_{\max }$ - végdiasztolés térfogat öszszefüggés meredekségét ( $\left.\mathrm{dP}_{\mathrm{dt}} \mathrm{dax}_{\mathrm{max}}-\mathrm{EDV}\right)$. A BK-i végdiasztolés nyomás-térfogat-összefüggés meredeksége (EDPVR) a BK-i falmerevség megbízható jelzője (17).

A P-V-analízis során a BK müködésének mechanoenergetikáját jellemző paramétereket mértünk és számítottunk a korábban leírtaknak megfelelően (18, 19). A mechanikus hatásfokot $\left(E_{\mathrm{ff}}\right)$ a verőmunka (SW) és a
P-V-terület (PVA) hányadosa határozta meg, amelyet PVAN szoftverrel számoltunk ki. Az artériás elasztanciát $\left(E_{a}\right)$ a következő képlet alapján számítottuk: LVESP/ $\mathrm{SV}$. A ventrikulo-arteriális kapcsolás (VAC) az $\mathrm{E}_{\mathrm{a}} / \mathrm{ES}$ PVR képlet alapján került kiszámításra.

A mellkas megnyitását követően oxigenált Ringer-oldatot $\left(37^{\circ} \mathrm{C}\right)$ infundáltunk a BK-ba a szívcsúcson keresztül, annak érdekében, hogy eltávolítsuk a vörösvértesteket a szívizomszövetből. A szív eltávolítását követő szívtömegmérés után BK-i izomszövetet konzerváltunk szövettani és molekuláris biológiai mérésekre. Végül megmértük az állat tibia-hosszát (TL) és erre normalizáltuk a szívtömeg-értékeket.

\section{Szövettan}

A BK-i szívizomszövet mintákat formalinban fixáltuk, majd paraffinba ágyaztuk. Ezen transzmurális szívizomszövetmetszetek (5 $\mu \mathrm{m}$ vastag) hematoxilin-eozin (HE) és picrosirius vörös festése után fénymikroszkóppal vizsgáltuk a szöveti szerkezetet. A HE festett metszeteken állatonként $100 \mathrm{db}$ hosszmetszetben elhelyezkedő, véletlenszerüen kiválasztott cardiomyocyta sejtmagján áthaladó harántátmérőjét mértük, majd az értékeket állatonként átlagoltuk. A picrosirius vörös festés esetében a szívizom kollagén tartalmát szoftver segítségével kvantifikáltuk.

\section{Kvantitatív valós idejú̃ polimeráz láncreakció (qRT-PCR)}

A konzervált szívizomszövet-mintákból RNS-t izoláltunk, majd reverz transzkripciót végeztünk kereskedelemben kapható kitek segítségével. cDNS-mintáinkból qRT-PCR reakciót hajtottunk végre miokardiális hipertrófia markerek: $\alpha$-miozin nehéz lánc ( $\alpha-M H C)$, $\beta$-miozin nehéz lánc ( $\beta-\mathrm{MHC})$, és pitvari natriuretikus peptid (ANF); endogén antioxidánsok: kataláz (Cat), szuperoxid-dizmutáz $2\left(\mathrm{SOD}_{2}\right)$, és tioredoxin-1 (TRX1); gyulladásos markerek: interleukin-1 $\beta$ (IL-1 $\beta$ ), tumornekrózis-faktor- $\alpha$ (TNF $\alpha)$, és transzformáló növekedési faktor- $\beta_{1}\left(\right.$ TGF $\left.\beta_{1}\right)$; továbbá mitokondriális markerek: peroxiszóma proliferátor-aktivált receptor gamma ko-

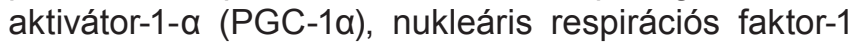
(NRF1), ösztrogénhez köthető receptor-a (ERRa), peroxiszóma proliferátor-aktivált receptor- $\alpha$ (PPAR $\alpha$ ), és citokróm-c (CytC) expressziójának vizsgálatára. Adatainkat a gliceraldehid-3-foszfát dehidrogenáz (GAPDH) expressziójára normalizáltuk.

\section{Statisztikai elemzés}

Minden adatot átlag士SEM formájában adtunk meg. Adataink normál eloszlásának igazolása (ShapiroWilks-teszt) után Student-féle kétmintás t-próbát használtunk. A kétfajta hipertrófia funkcionális összehasonlítása során az egyes hipertrófiás állatok értékeit az adott kontrollállatok átlagértékére normalizáltuk, majd ezen normalizált adatokat hasonlítottuk össze Student-féle kétmintás t-próbával. $A p<0,05$ értéket tekintettük statisztikailag szignifikánsnak. 


\section{Eredmények}

Testtömeg- és szívtömeg-adatok

A sportoló patkányok testtömege csökkent a kontrollok-

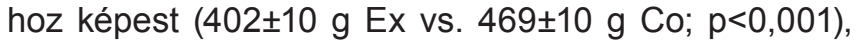
míg a patológiás hipertrófia modellállatainak tömege

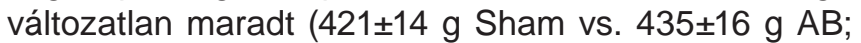
$p=0,517)$. A tibiahosszra normalizált szívtömeg-értékek a fiziológiás és patológiás hipertrófiában magasabbnak adódtak (1. A ábra).

\section{Echokardiográfia}

A szívultrahangos mérések adatait az 1. táblázat mutatja. Mindkét modellben megnövekedett az LVAWT és LVPWT szisztoléban és diasztoléban. Míg az LVEDD
A

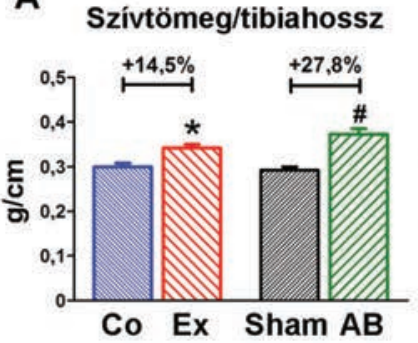

B

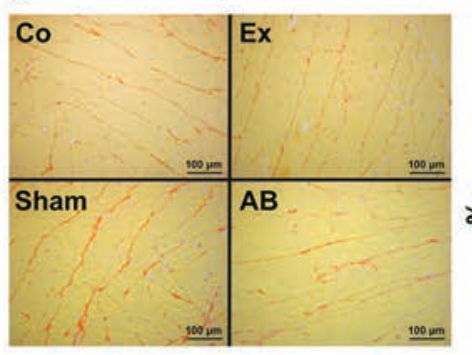

BK-i izomtömeg index

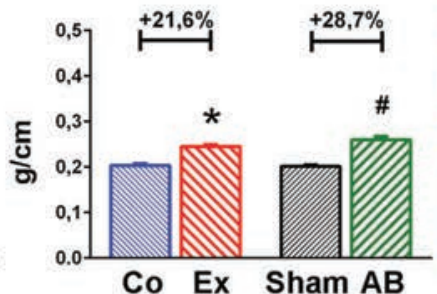

Co Ex Sham AB

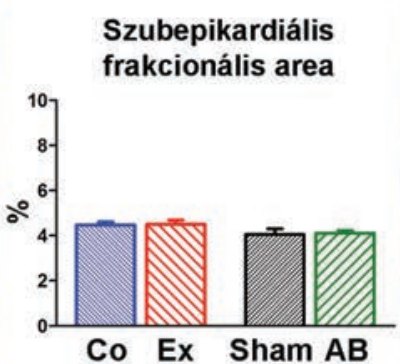

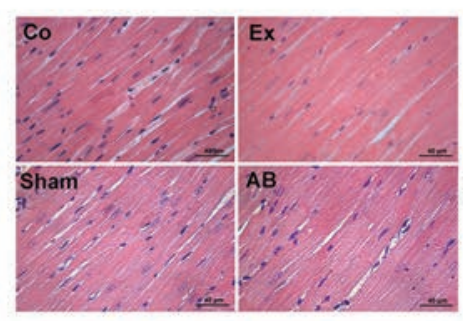
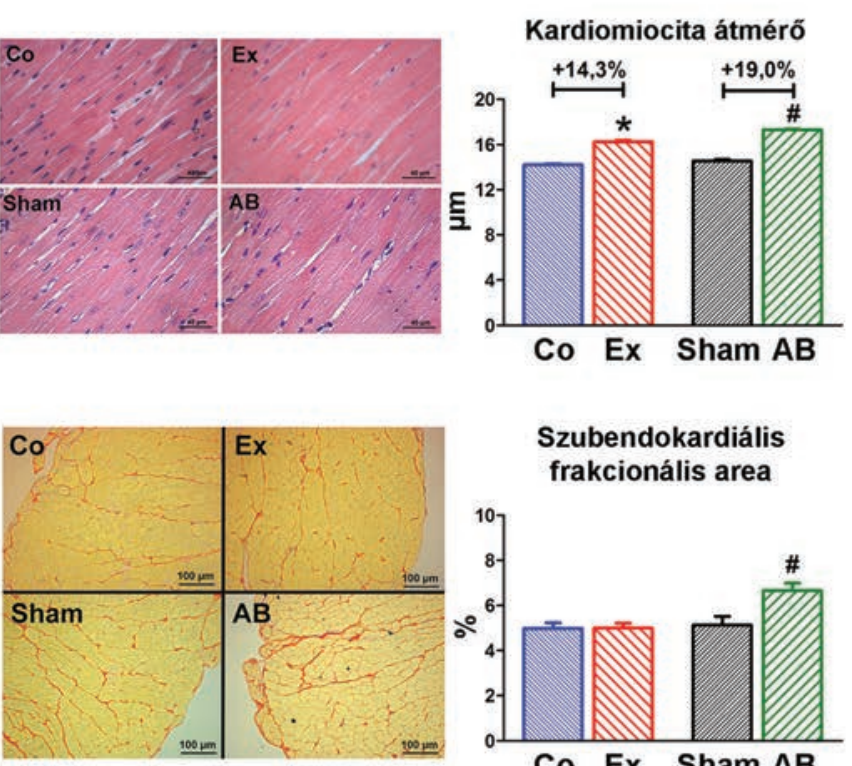

Szubendokardiális frakcionális area

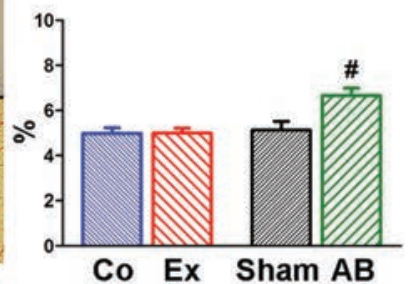

1. ÁBRA. A bal kamrai (BK) hipertrófia jellemzése. A: poszt-mortem mért, tibiahosszra normalizált szívtömeg-értékek és szívultrahanggal meghatározott BK-izomtömegindex, továbbá szövettani elemzés során a BK-i cardiomyocyták átlagos átmérője emelkedett értékeket mutattak az úszó (Ex) és aorta szúkített (AB) állatokban a kontrollokhoz (Co és Sham) képest. Ez BK-hipetrófiára utal mindkét modell esetében. B: picrosirius vörös festéssel (ahol a vörös festődésű területek a kollagén rostokat mutatják) változatlan kollagénsűrűséget detektáltunk fiziológiás hipertrófiában. Ezzel szemben patológiás szívizom-megnagyobbodás során szubendokardiális fibrózist találtunk (a jobb alsó képen, az AB-csoport metszetén nagyobb területű vörös festődés látható). Az értékeket átlag \pm szórás formában tüntettük fel. * $p<0,05$ vs. Co; ${ }^{\sharp}<<0,05$ vs. Sham

1. TÁBLÁZAT. Szívultrahang-adatok

Fiziológiás hipertrófia

\section{Patológiás hipertrófia}

\begin{tabular}{|c|c|c|c|c|c|c|}
\hline & Co & Ex & p-érték & Sham & $\mathbf{A B}$ & p-érték \\
\hline HR (ütés/min) & $357 \pm 15$ & $351 \pm 10$ & 0,719 & $378 \pm 24$ & $382 \pm 11$ & 0,874 \\
\hline LVAWTd (mm) & $1,96 \pm 0,02$ & $2,17 \pm 0,02$ & $<0,001$ & $1,95 \pm 0,02$ & $2,19 \pm 0,03$ & $<0,001$ \\
\hline LVAWTs (mm) & $3,02 \pm 0,05$ & $3,37 \pm 0,06$ & $<0,001$ & $2,94 \pm 0,10$ & $3,32 \pm 0,07$ & 0,005 \\
\hline LVPWTd (mm) & $1,82 \pm 0,03$ & $1,93 \pm 0,02$ & 0,001 & $1,78 \pm 0,01$ & $2,06 \pm 0,04$ & $<0,001$ \\
\hline LVPWTs (mm) & $2,91 \pm 0,04$ & $3,09 \pm 0,04$ & 0,007 & $2,84 \pm 0,06$ & $3,09 \pm 0,04$ & 0,002 \\
\hline LVEDD (mm) & $6,85 \pm 0,05$ & $6,89 \pm 0,03$ & 0,527 & $6,79 \pm 0,08$ & $6,95 \pm 0,08$ & 0,199 \\
\hline LVESD (mm) & $4,06 \pm 0,08$ & $3,45 \pm 0,09$ & $<0,001$ & $3,99 \pm 0,17$ & $4,22 \pm 0,11$ & 0,245 \\
\hline FS (\%) & $41,4 \pm 0,7$ & $50,0 \pm 1,1$ & $<0,001$ & $41,3 \pm 2,3$ & $40,5 \pm 1,3$ & 0,739 \\
\hline EF (\%) & $65,5 \pm 1,3$ & $73,0 \pm 1,3$ & $<0,001$ & $65,1 \pm 1,5$ & $62,4 \pm 1,3$ & 0,191 \\
\hline LV-mass (g) & $0,87 \pm 0,01$ & $0,98 \pm 0,01$ & $<0,001$ & $0,85 \pm 0,02$ & $1,03 \pm 0,02$ & $<0,001$ \\
\hline LV-mass index, $(\mathrm{g} / \mathrm{cm})$ & $0,202 \pm 0,004$ & $0,246 \pm 0,003$ & $<0,001$ & $0,202 \pm 0,003$ & $0,260 \pm 0,007$ & $<0,001$ \\
\hline
\end{tabular}

Az értékeket átlag \pm szórás formában tüntettük fel. HR: szívfrekvencia; bal kamrai anterior (LVAWT) és posterior (LVPWT) falvastagság-értékek végszisztoléban (index: s) és végdiasztoléban (index: d); FS: frakcionális rövidülés; LV-mass: bal kamrai izomtömeg; LV-mass index (tibiahosszra normalizált LV-mass) bal kamrai végdiasztolés (LVEDD) és végszisztolés (LVESD) átmérők; SV: FS: frakcionális rövidülés; EF: ejekciós frakció 
változatlan maradt, addig az LVESD csökkent fiziológiás hipertrófiában. Patológiás hipertrófia esetében változatlan kamrai dimenziókat találtunk. Ebből adódóan az FS és EF, a szisztolés funkció hagyományos paraméterei, az úszó állatokban megemelkedtek, míg az aortaszúkített patkányokban változatlanok maradtak. Mindkét hipertrófiás csoportban markánsan emelkedett LV-mass és LV-mass index értékeket találtunk, amely hasonló fokú BK-i hipertrófiát jelzett a két modellben (1. táblázat és 1.A ábra).

\section{Hemodinamikai mérések}

A 2. ábra mutatja a Co, Ex, Sham, és AB-csoportok egy-egy reprezentatív állatának jellegzetes P-V-hurkait. Az úszó patkányokban ezen hurkok kiszélesedését figyeltük meg. Az AB-patkányokban a hurkok enyhe fokú jobbratolódását és jelentősen emelkedett végszisztolés nyomásértékeket detektáltunk nyugalomban. A 2. táblázat mutatja, hogy az úszó állatokban az LVESV csökkent, míg a HR, MAP, BK-i nyomásértékek, dP/dt $\mathrm{max}_{\max }$, és $\mathrm{dP} / \mathrm{dt}_{\min }$ értékek változatlanok maradtak. Ebből adódóan a sportoló patkányokban emelkedett SV, EF, CO, és Cl-paramétereket dokumentáltunk a kontrollállatokhoz képest. A nyomástúlterhelés okozta patológiás hipertrófia esetében emelkedett MAP, LVESP, és $\mathrm{dP} / \mathrm{dt}_{\max }$ értékeket regisztráltunk változatlan HR, LVEDP, és dP/ $\mathrm{dt}_{\text {min }}$ mellett. Az LVEDV, LVESV és SV csak tendenciális növekedést mutatott, tehát az EF, CO és $\mathrm{Cl}$ nem különbözött a Sham és AB-csoportok között.

A BK-i relaxáció terheléstől független mutatója, a $\tau$, szignifikánsan javult fiziológiás hipertrófiában, azonban patológiás szívizom-megnagyobbodás esetén nagymértékben romlott (2. táblázat és 4. ábra).

A 3. ábra csoportonként egy-egy állat reprezentatív $\mathrm{P}-\mathrm{V}$ hurkait mutatja be csökkenő előterhelés mellett.

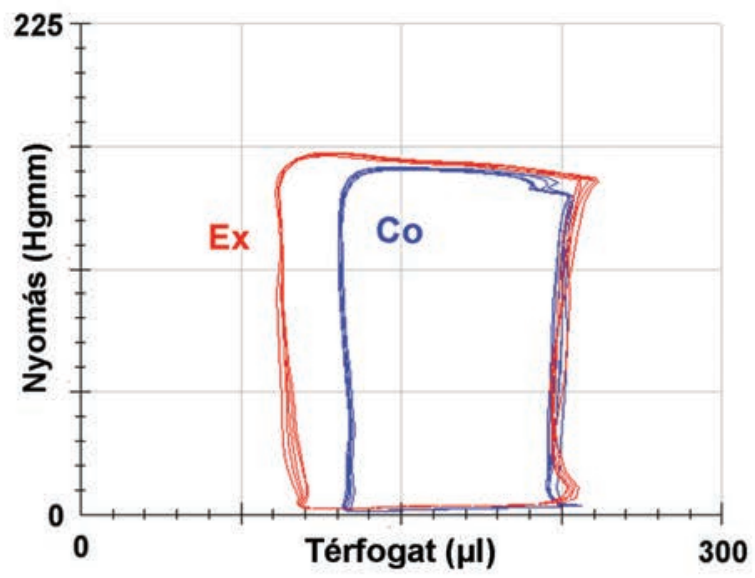

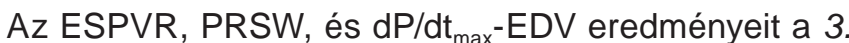
ábra demonstrálja. Mindhárom érzékeny kontraktilitási paraméter hasonló mértékben növekedett a két típusú hipertrófiában (3. és 4. ábra). Emellett ezen paraméterek pozitív lineáris összefüggést mutattak a BK izomtömegértékekkel valamennyi állat adatait figyelembe véve (3. ábra).

Meghatároztuk az EDPVR-t, amely a BK-i falmerevség érzékeny mutatója. Értéke egyik hipertrófia típusban sem mutatott szignifikáns különbséget (2. táblázat, 4. ábra).

A mechanoenergetikát illetően eredményeink az SW megnövekedését mutatták mindkét modellben. A PVA azonban csak a patológiás hipertrófiában emelkedett meg (5. ábra). Ebből adódóan a BK-i funkció mechanikus hatásfoka javult a fiziológiás, míg változatlan maradt a patológiás szívizom-megnagyobbodás modelljében (5. ábra). Emellett a VAC kedvezőbb ventrikulo-arteriális kölcsönhatást mutatott az úszó állatokban a kontrollokhoz képest, míg változatlan maradt az aortaszükített állatok esetén (2. táblázat).

\section{Szövettan}

Megnövekedett cardiomyocyta átmérőt találtunk az úszó és aortaszúkített csoportokban a kontrollokhoz képest (1. A ábra). A picrosirius vörös festés nem mutatott kollagénlerakódást az úszó állatok myocardiumában. Ezzel szemben patológiás hipertrófiában szubendokardiálisan (de nem szubepikardiálisan) emelkedett kollagéntartalmat találtunk (1. B ábra).

\section{Génexpresszió}

Az ANF és $\beta-M H C$ miokardiális génexpressziója markáns növekedést mutatott, míg az $\alpha-\mathrm{MHC}$ csökkent (ennek eredményeképpen csökkent az $\alpha-\mathrm{MHC} / \beta-\mathrm{MHC}$

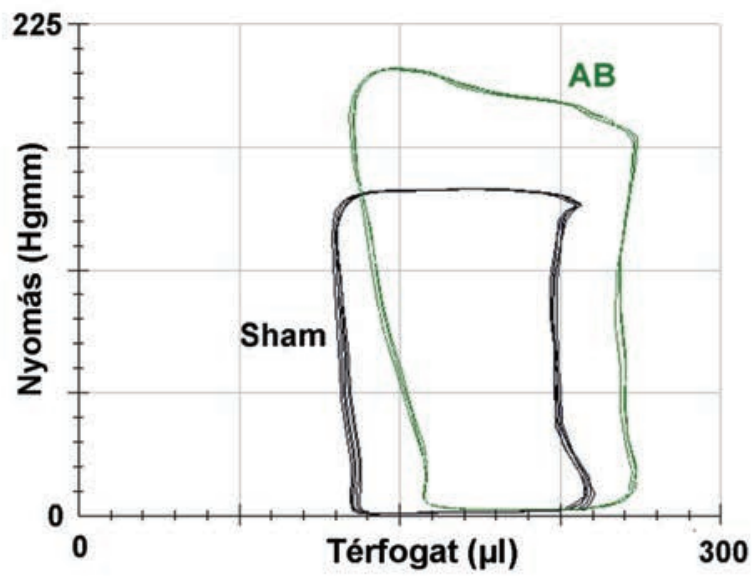

2. ÁBRA. Nyugalmi nyomás-térfogat (P-V) hurkok. Az Ex, Co, $A B$, és Sham csoport egy-egy állatának reprezentatív nyugalmi P-V-hurkait szemlélteti. A bal oldali P-V-diagrammon az edzett állatok esetén megfigyelt kiszélesedett P-V-hurkok emelkedett verőtérfogatra utalnak, amely megtartott végdiasztolés térfogat mellett a csökkent végszisztolés térfogat következménye. A nyomástúlterheléssel összefüggő patológiás hipertrófiában markánsan emelkedett bal kamrai szisztolés nyomást továbbá tendenciálisan növekvő végszisztolés és végdiasztolés térfogatot (a P-V-hurkok enyhe mértékű jobbratolódása) regisztráltunk a Sham csoporthoz viszonyítva 

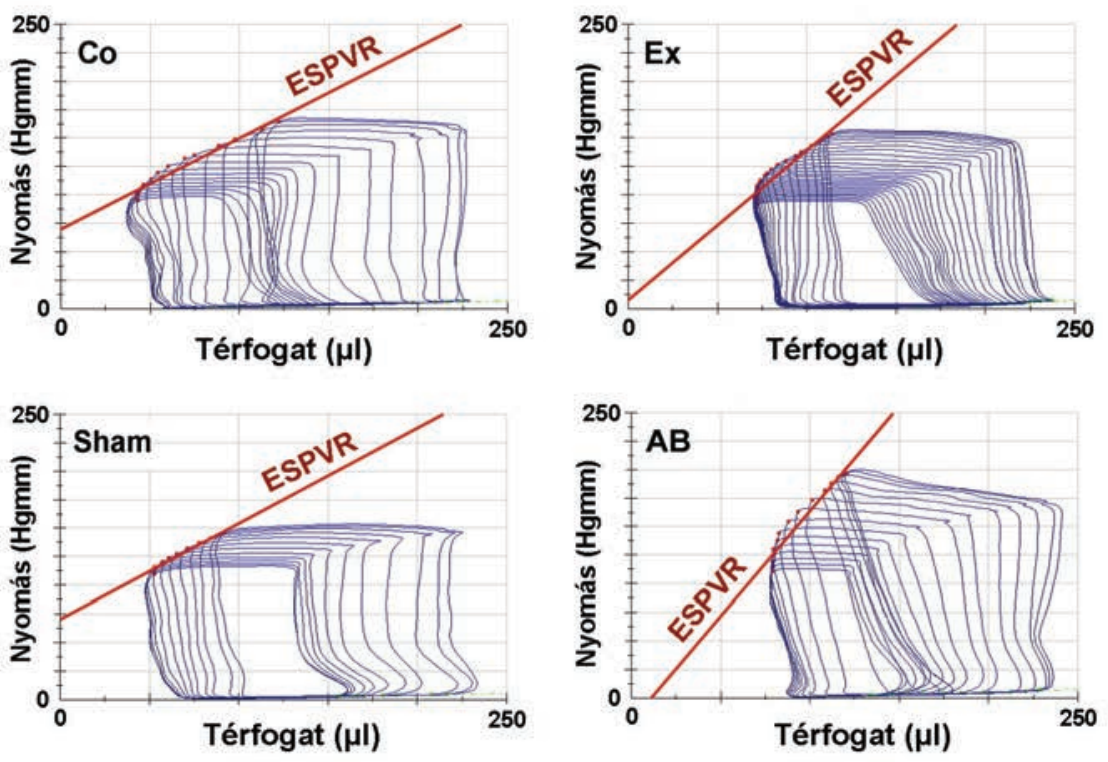

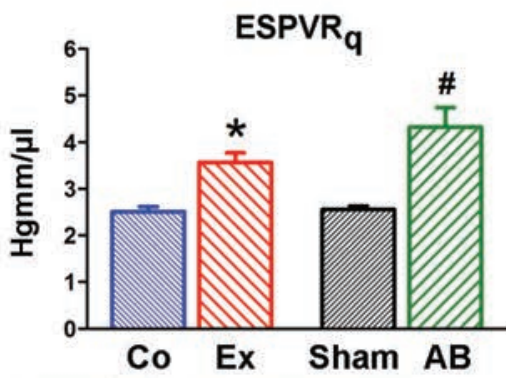

Korreláció: BK-i izomtömeg - ESPVR

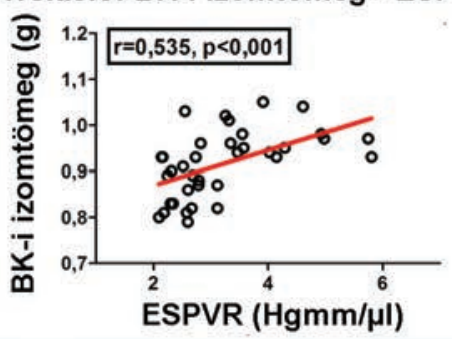

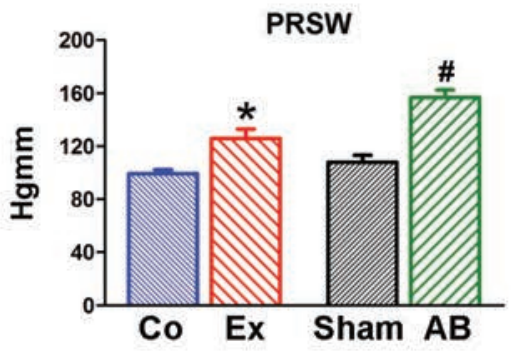

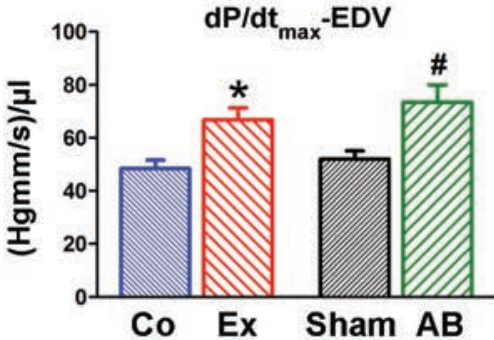

3. ÁBRA. Bal kamrai (BK) kontraktilitás fiziológiás és patológiás szívizom-hipertrófiában. Nyomás-térfogat (P-V) analízis során érzékeny, terheléstől független BK-i kontraktilitás paraméterek számíthatók, a szív előterhelésének fokozatos csökkentésével. Az ábra felső részén előterhelést csökkentő manőver során regisztrált reprezentatív $\mathrm{P}-\mathrm{V}$-hurkok láthatók. A végszisztolés P-V-összefüggés meredeksége (ESPVRq) megnövekedett az Ex és AB-csoportokban a Co és Sham csoportokhoz képest. A kontraktilitás ezen érzékeny paramétere erős korrelációt mutatott a BK-i izomtömeg mértékével. Két másik érzékeny kontraktilitás paraméter, a verőmunka - végdiasztolés térfogat-összefüggés meredeksége (PRSW) és maximális dP/ $\mathrm{dt}$ - végdiasztolés térfogat-összefüggés meredeksége ( $\left.\mathrm{dP} / \mathrm{dt} \mathrm{t}_{\max }-\mathrm{EDV}\right)$ megnövekedett mindkét hipertrófia típusban. Az értékeket átlag \pm szórás formában tüntettük fel. * $p<0,05$ vs. Co; ${ }^{*} p<0,05$ vs. Sham

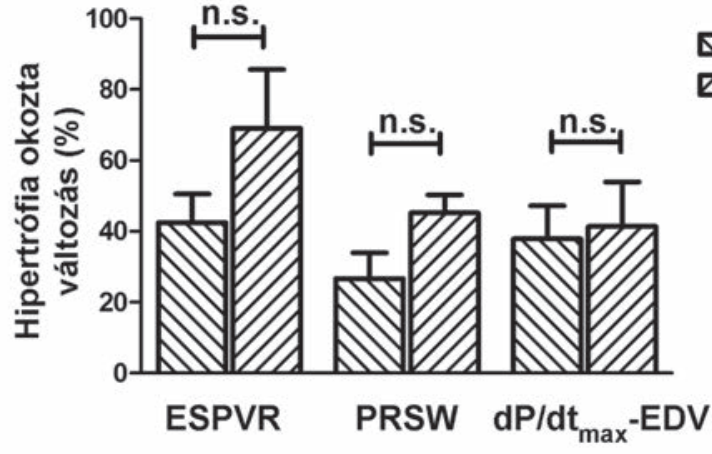

BK-i kontraktilitás
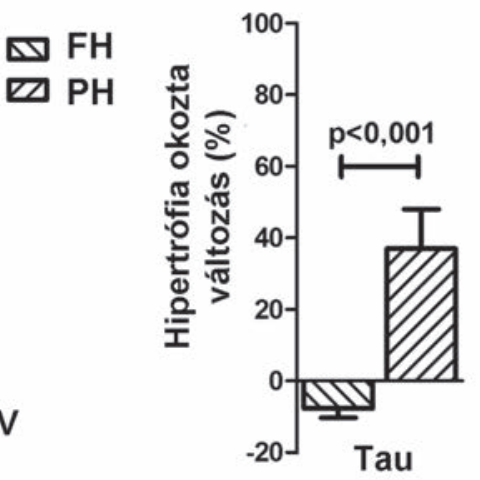

Aktív relaxáció

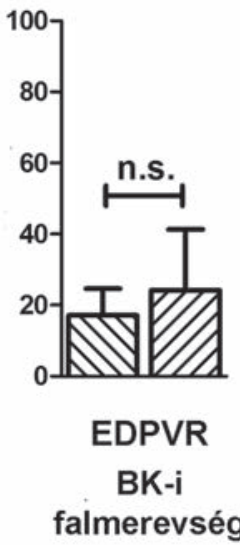

falmerevség

4. ÁBRA. A bal kamrai (BK) funkciót jellemző, érzékeny paraméterek változásainak direkt összehasonlítása fiziológiás és patológiás szívizom-hipertrófia esetén. Az érzékeny BK-i kontraktilitás-paraméterek, mint a végszisztolés nyomás-térfogat-összefüggés meredeksége (ESPVR), a verőmunka - végdiasztolés térfogat-összefüggés meredeksége (PRSW) és a szisztolés nyomásnövekedés maximális sebessége - végdiasztolés térfogat összefüggés meredeksége ( $\left.\mathrm{dP} / \mathrm{dt}_{\max }-\mathrm{EDV}\right)$, hasonló mértékben növekedett $B K-\mathrm{i}$ kontraktilitást mutattak a fiziológiás (FH) és patológiás (PH) hipertrófia esetén. A diasztolé kezdetét, vagyis a BK-i relaxációt terheléstől függetlenül jellemző marker, a Tau $(\tau)$ esetében markáns különbség adódott. A fiziológiás hipertrófiában megfigyelhető javult diasztolés funkcióra utal a csökkent $\tau$, míg patológiás hipertrófiában az aortaszúkítésen átesett állatok esetében az aktív relaxáció markáns romlását figyeltük meg (megnövekedett $\tau$ ). Mindkét hipertrófiatípus esetében a BK-falmerevség tendenciális növekedését találtuk, a két modell közötti különbség nélkül. Az értékeket átlag士szórás formában tüntettük fel. ns., nem szignifikáns 
2. TÁBLÁZAT: Hemodinamikai adatok

\begin{tabular}{|c|c|c|c|c|c|c|}
\hline & \multicolumn{3}{|c|}{ Fiziológiás hipertrófia } & \multicolumn{3}{|c|}{ Patológiás hipertrófia } \\
\hline & Co & Ex & p-érték & Sham & $\mathbf{A B}$ & p-érték \\
\hline HR, ütés/min & $412 \pm 9$ & $400 \pm 8$ & 0,329 & $429 \pm 15$ & $434 \pm 11$ & 0,794 \\
\hline MAP, Hgmm & $145,3 \pm 2,8$ & $142,1 \pm 5,2$ & 0,586 & $142,0 \pm 2,0$ & $182,3 \pm 7,9$ & $<0,001$ \\
\hline LVESP, Hgmm & $154,8 \pm 3,4$ & $152,2 \pm 8,2$ & 0,761 & $150,8 \pm 2,0$ & $213,4 \pm 6,8$ & $<0,001$ \\
\hline LVEDP, Hgmm & $3,0 \pm 0,2$ & $3,7 \pm 0,4$ & 0,151 & $3,9 \pm 0,7$ & $4,4 \pm 0,4$ & 0,374 \\
\hline $\mathrm{dP} / \mathrm{dtmax}, \mathrm{Hgmm} / \mathrm{s}$ & $9,237 \pm 397$ & $9,847 \pm 659$ & 0,439 & $9,103 \pm 424$ & $12,185 \pm 399$ & $<0,001$ \\
\hline $\mathrm{dP} / \mathrm{dtmin}, \mathrm{Hgmm} / \mathrm{s}$ & $-12,191 \pm 443$ & $-12,213 \pm 670$ & 0,979 & $-12,390 \pm 261$ & $-12,506 \pm 676$ & 0,887 \\
\hline$\tau, \mathrm{ms}$ & $12,1 \pm 0,3$ & $11,2 \pm 0,3$ & 0,036 & $11,7 \pm 0,6$ & $16,6 \pm 1,3$ & 0,006 \\
\hline LVEDV, $\mu \mathrm{l}$ & $234,4 \pm 5,2$ & $239,2 \pm 6,1$ & 0,552 & $239,9 \pm 7,2$ & $261,7 \pm 9,1$ & 0,100 \\
\hline LVESV, $\mu l$ & $111,5 \pm 2,0$ & $98,6 \pm 2,3$ & $<0,001$ & $105,7 \pm 4,8$ & $114,4 \pm 5,1$ & 0,179 \\
\hline SV, $\mu \mathrm{l}$ & $123,1 \pm 5,5$ & $140,6 \pm 4,8$ & 0,026 & $134,2 \pm 7,0$ & $147,2 \pm 6,3$ & 0,193 \\
\hline$E F, \%$ & $52,2 \pm 1,4$ & $58,3 \pm 0,8$ & 0,001 & $55,9 \pm 2,1$ & $56,3 \pm 1,3$ & 0,861 \\
\hline $\mathrm{CO}, \mathrm{ml} / \mathrm{min}$ & $50,6 \pm 2,0$ & $56,2 \pm 1,5$ & 0,037 & $58,5 \pm 3,9$ & $63,7 \pm 2,8$ & 0,281 \\
\hline $\mathrm{Cl},(\mathrm{ml} /$ perc) $/ 100 \mathrm{~g} \mathrm{BW}$ & $10,9 \pm 0,5$ & $14,2 \pm 0,4$ & $<0,001$ & $13,8 \pm 1,1$ & $14,7 \pm 0,7$ & 0,485 \\
\hline $\mathrm{SW}, \mathrm{Hgmm} \cdot \mathrm{ml}$ & $14,7 \pm 0,8$ & $18,0 \pm 0,8$ & 0,009 & $15,6 \pm 1,2$ & $22,7 \pm 1,2$ & 0,001 \\
\hline 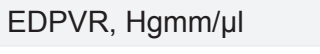 & $0,036 \pm 0,003$ & $0,042 \pm 0,003$ & 0,131 & $0,034 \pm 0,004$ & $0,042 \pm 0,006$ & 0,256 \\
\hline TPR, Hgmm/(ml/perc) & $2,91 \pm 0,09$ & $2,54 \pm 0,12$ & 0,034 & $2,52 \pm 0,18$ & $2,95 \pm 0,22$ & 0,167 \\
\hline $\mathrm{Ea}, \mathrm{Hgmm} / \mu \mathrm{l}$ & $1,33 \pm 0,05$ & $1,09 \pm 0,08$ & 0,021 & $1,07 \pm 0,05$ & $1,48 \pm 0,07$ & 0,001 \\
\hline VAC & $0,53 \pm 0,03$ & $0,32 \pm 0,03$ & $<0,001$ & $0,42 \pm 0,02$ & $0,37 \pm 0,03$ & 0,188 \\
\hline
\end{tabular}

Az értékeket átlag士szórás formában tüntettük fel. MAP: artériás középnyomás; LVESP és LVEDP: bal kamrai végszisztolés, illetve végdiasztolés nyomás; LVEDV és LVESV: bal kamrai végdiasztolés, illetve végszisztolés térfogat; SV: verővolumen; CO: perctérfogat; Cl: szívindex; EF: ejekciós frakció; SW: bal kamrai verőmunka; $\mathrm{dP}_{\mathrm{dt}}$ max és $\mathrm{dP} / \mathrm{dt}_{\min }$ : maximális, illetve minimális $\mathrm{dP} / \mathrm{dt}$; Tau: bal kamrai relaxációs időkonstans; TPR: teljes perifériás ellenállás; $\mathrm{E}_{\mathrm{es}}$ : bal kamrai végszisztolés nyomás-térfogat összefüggés meredeksége; $\mathrm{E}_{\mathrm{PPv}}$ : bal kamrai végdiasztolés nyomás-térfogat összefüggés meredeksége; PRSW: a verömunka-végdiasztolés térfogat összefüggés meredeksége; $\mathrm{dP} / \mathrm{dt}_{\max }$-EDV: a maximális $\mathrm{dP} / \mathrm{dt}$-végdiasztolés térfogat összefüggés meredeksége; $\mathrm{E}_{\mathrm{a}}$ : artériás elasztancia; Maximal power: maximális bal kamrai teljesítmény; PVA: nyomás-térfogat-terület; VAC: ventrikulo-arteriális kapcsolás

arány) patológiás hipertrófiában. Ezen patológiás hipertrófiamarkerek expressziója úszókban nem különbözött a kontrollokhoz képest (6. A ábra). Az antioxidáns és gyulladásos markerek expressziója tekintetében a csoportok között nem volt különbség (6. B-C ábra). A mitokondriális funkcióval összefüggő markerek expressziója (PGC-1a, NRF1, PPARa, és $(y t C)$ nem változott fiziológiás hipertrófiában. Ezzel szemben ezen gének expressziója csökkent pa- tológiás szívizom-megnagyobbodásban, amely jellegzetes különbség a két hipertrófia típus között (6. $D$ ábra).

\section{Megbeszélés}

Jelen tanulmány az első, amely direkt, részletes hemodinamikai összehasonlítást ad a fiziológiás és patológi-
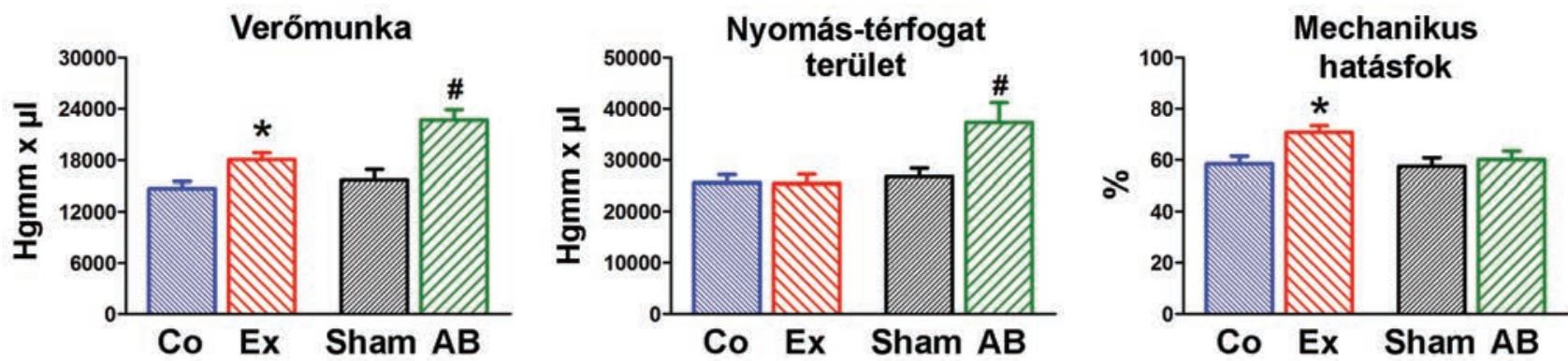

5. ÁBRA. Bal kamrai (BK) mechanoenergetika. A verőmunka, a BK effektív mechanikus munkája, mindkét modell esetében emelkedett volt. A nyomás-térfogat terület, amely a BK-i energiaigénnyel mutat összefüggést, megnövekedett az AB-patkányokban a Sham állatokhoz képest. Ez a paraméter azonban nem különbözött fiziológiás hipertrófiában a kontrollokhoz képest. Következésképpen a BK mechanikus hatásfoka javult a fiziológiás, míg változatlan maradt a patológiás szívizom-megnagyobbodás modelljében. Az értékeket átlag士szórás formában tüntettük fel. Co: kontroll, Ex: edzett, Sham: áloperált, AB: aortaszűktett csoport 

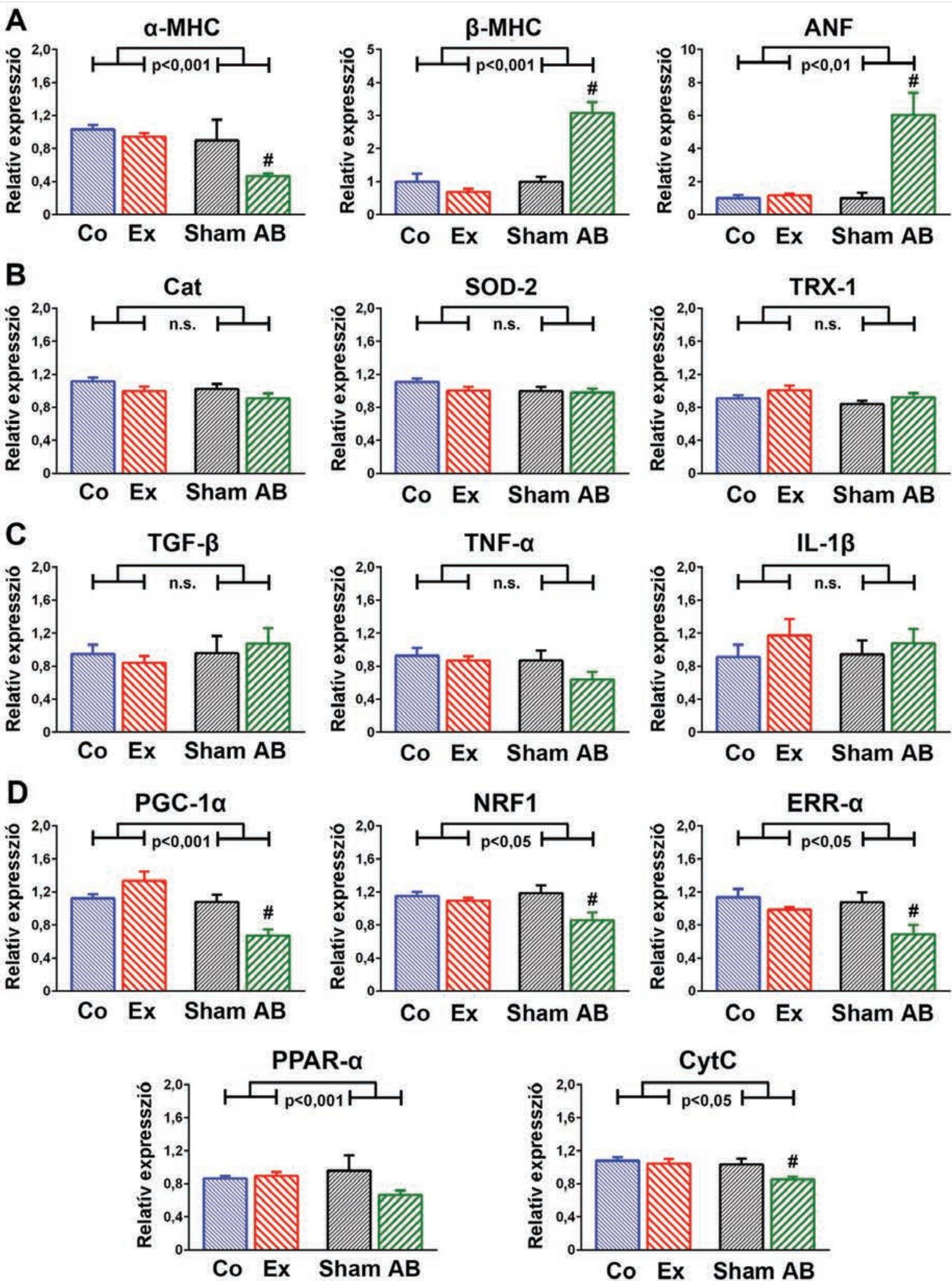

6. ÁBRA. Miokardiális génexpresszió. A miokardiális hipertrófia markerek: $\alpha$-miozin nehéz lánc ( $\alpha$-MHC), B-miozin nehéz lánc (B-MHC), és pitvari natriuretikus peptid (ANF); endogén antioxidánsok: kataláz (Cat), szuperoxid-dizmutáz-2 ( $\left.\mathrm{SOD}_{2}\right)$, és tioredoxin-1 (TRX1); gyulladási markerek: interleukin-1ß (IL-1ß), tumornekrózis-faktor- $\alpha$ (TNF $\alpha$ ), és transzformáló növekedési faktor- $\beta_{1}\left(T G F \beta_{1}\right)$; továbbá mitokondriális markerek: peroxiszóma proliferátor-aktivált receptor gamma koaktivátor $1 \alpha$ (PGC-1 $\alpha$ ), nukleáris respirációs faktor-1 (NRF1), ösztrogén-rokon receptor- $\alpha$ (ERR $\alpha$ ), peroxiszóma proliferátor-aktivált receptor- $\alpha$ (PPAR $\alpha$ ), és citokróm-c (CytC) relatív expressziója a Co, Ex, Sham, és AB-patkányokban. Az ábrák közepén látható szignifikancia-értékek a két modell közvetlen összehasonlítására vonatkoznak. Az értékeket átlag士szórás formában tüntettük fel. * ${ }^{*}<0,05$ vs. Co; \#p<0,05 vs. Sham. ns., nem szignifikáns 
ás BK-i hipertrófiáról nyomás-térfogat-analízis segítségével, releváns kisállatmodelleken.

A szívizom-hipertrófia a myocardium válasza olyan különféle ingerekre, amelyek megnövekedett biomechanikai stresszt váltanak ki. A szívizomsejtek méretének megnövekedése, a fokozott fehérjeszintézis, és a szarkomerek magasabb fokú szerveződése olyan morfológiai változásokat eredményeznek, amelyek a hipertrófiás fenotípus kialakulását eredményezik (20). Eredményeink alapján mind az aortaszükítés, mind az intenzív úszóedzés a BK-i falvastagság szignifikáns növekedéséhez, koncentrikus BK-hipertrófiához vezetett (1. táblázat). Habár úszóedzés hatására sportolókban a BK dilatációja volt megfigyelhető (25), patkányainkban a végdiasztolés dimenzió változatlannak bizonyult, amelyet magyarázhat a rágcsálók és az ember közötti jelentős szívfrekvencia-különbség, vagy a mérések során alkalmazott anesztézia befolyásoló hatása is. A BK-i izomtömegindex rámutatott arra, hogy a BK-hipertrófia mértéke hasonlónak adódott a két modellben, valamint összehasonlítható mértékü korábbi kutatási eredményeinkkel (14) és más tanulmányban leírtakkal (2, 21, 22). A BK-i szívizomsejtek átmérőjének értékei szövettani kiértékelése során alátámasztották a BK-hipertrófia jelenlétét mindkét modellben (1. ábra). A változatlan BK-dimenziók, valamint FS- és EF-értékek rávilágítottak arra, hogy AB-patkányok esetében nem volt jelen patológiás hipertrófiához társuló tágulás, amely összefügg korábbi aortaszűkítéssel foglalkozó tanulmányok eredményeivel (1. táblázat) $(10,23)$.

A kollagén állományának megnövekedése 6 hét aortaszükítés elteltével csak a subendocardiumra lokalizáltan volt megfigyelhető (1. B ábra). Ez összhangban áll egy hasonló modellen végzett vizsgálattal, amely szubendokardiális kollagén-lerakódást igazolt 2 hónapos krónikus nyomástúlterhelés mellett (10). A hosszú távú fizikai edzés esetén hiányzó kötőszöveti átépülés a BK-hipertrófia fiziológiás természetét támasztja alá (22).

Az edzéshez társuló szívizom-megnagyobbodással ellentétben a patológiás hipertrófia a miokardiális fötális génprogram reaktivációjával jár (20). A széles körben vizsgált patológiás hipertrófia marker $\alpha-\mathrm{MHC}, \beta-\mathrm{MHC}$ és ANF miokardiális génexpressziója tisztán demonstrálta a BK-hipertrófia fiziológiás, illetve patológiás természetét az Ex- és AB-patkányok esetében (6. $A$ ábra) $(2,8)$. A patológiás hipertrófia szívelégtelenségbe történő progressziója megnövekedett miokardiális oxidatív stresszel és gyulladással társul (1). A hasi aortaszűkítést követő 6 . héten megfigyelt endogén antioxidánsok és gyulladásos citokinek változatlan miokardiális expressziója utalhat arra, hogy az intenzív oxidatív stressz és a következményes gyulladásos válasz ezen kompenzált fázisra nem jellemző (6. B, C ábra). Az oxidatív stressz és gyulladásos markerek változatlan expreszsziója várható volt az szakirodalmi adatok alapján (8). A 2. ábra világosan szemlélteti, hogy az úszó állatok esetében - hasonló bal kamrai nyomás és frekvencia mellett - változatlan végdiasztolés, illetve csökkent végszisztolés dimenziókat figyeltünk meg, amely által emelkedett verőtérfogat mutatkozott, amely összhangban áll sportolókon végzett noninvazív mérések eredményeivel (2. ábra és 2. táblázat) $(24,25)$.

A 2. táblázat mutatja, hogy a hasi aortaszűkítés hatására jelentős mértékben emelkedett a BK-i végszisztolés nyomás, amely növekedés összemérhető a korábban megfigyeltekkel kisállat-modellek esetén $(2,26)$. A nyugalmi BK-i P-V-hurkok enyhe jobbratolódást mutattak, amely változást korábban is kimutatták a nyomástúlterhelés hatására kifejlődő szívizom-megnagyobbodás esetén (27). Azonban számottevő tágulást nem detektáltunk, ami a patológiás hipertrófia kompenzált stádiumára utal.

A szisztolés funkció konvencionális paraméterei, a szívultrahanggal meghatározott BK-i FS és EF, illetve $\mathrm{P}-\mathrm{V}$-analízissel mért EF-emelkedést mutattak a sportoló állatokban, amely a megnövekedett BK-i szisztolés teljesítményre utal fiziológiás hipertrófia esetében (2. táblázat). Ezen paraméterek változatlanok voltak a 6 hetes nyomástúlterhelést követően, utalva a megtartott szisztolés funkcióra, amely adataink összhangban állnak egy korábbi tanulmány eredményeivel (10). A BK-i szisztolés funkció másik hagyományos, ugyanakkor elő- és utóterheléstől függő paramétere, a szisztolés nyomásnövekedés maximális sebessége ( $\left.\mathrm{dP}_{\mathrm{d}} \mathrm{dt}_{\max }\right)$ (28). Következésképpen a sportoló állatoknál megfigyelhető potenciális előterhelés-változás és az AB-patkányokra jellemző nagymértékű BK-i utóterhelés ezen paramétert megbízhatatlanná teszi.

A BK-i kontraktilitás precízen meghatározható $\mathrm{P}-\mathrm{V}$ analízis segítségével. A P-V-összefüggések rögzítése tranziens, előterhelést csökkentő manőver (vena cava inferior okklúzió) során lehetőséget teremt a töltéstől független BK-i kontraktilitás paraméterek kiszámítására (17). A leginkább elterjedt ilyen érzékeny kontraktilitásindex az ESPVR, amely mind az úszó, mind az AB-csoportban megnövekedett (3. ábra). Ugyanezt tapasztaltuk a PRSW és $\mathrm{dP}_{\mathrm{dt}} \mathrm{max}_{\text {max }}$ EDV esetén is, amely egyértelműen emelkedett kontraktilitásra utal mindkét modellben. Ezen adataink összhangban állnak a fiziológiás hipertrófiát vizsgáló előző tanulmányunk (14), illetve korábbi nyomástúlterhelés következtében létrejövő patológiás hipertrófiát elemző kutatások eredményeivel $(29,30)$. A kontraktilitás változása szempontjából nem volt szignifikáns különbség a két hipertrófia modell között (4. ábra). Mindemellett a kontraktilitás (ESPVR) összefüggést mutatott a BK-i hipertrófia mértékével (amit a BK-i izomtömeg képvisel). Ez alátámasztja azt a nézetet, hogy a BK-hipertrófia egy adaptív válasz, amely perctérfogat fenntartását célozza a megnövekedett biomechanikai stresszel szemben, legyen a kiváltó inger fiziológiás vagy patológiás (20).

A kamrai ciklus diasztolés fázisának két fő komponense jellemezhető $\mathrm{P}-\mathrm{V}$-analízis segítségével: az aktív re- 
laxáció és a bal kamra falmerevsége. A BK-i relaxáció egy aktív, energiafüggő mechanizmusnak tekinthető, amely leginkább a szarkoplazmás retikulumnak a korai diasztolé során történő kalciumion újrafelvételétöl függ (31). A BK-i nyomáscsökkenés időkonstansa $(\tau)$ a BK-i aktív relaxáció előterheléstől viszonylag független jellemzője (31). Fiziológiás hipertrófia esetén a csökkent $\tau$ értékek javult relaxációt jeleztek, vagyis rövidebb idejü az izovolumetriás relaxáció szakasza (2. táblázat). Ez összhangban áll a sportszívvel kapcsolatos korábban publikált eredményeinkkel (14). Ezzel szemben számottevően megnyúlt relaxációt találtunk a patológiás hipertrófia esetében (2. táblázat, 4. ábra), amely összhangban áll korábbi tanulmányokkal $(26,28,30)$. Az aktív relaxációban észlelhető karakterisztikus különbség összhangban áll humán szívultrahang-tanulmányok eredményeivel, amelyek szerint a hipertrófiás cardiomyopathia és a sportszív a korai diasztolés komponensek alapján különíthető el $(32,33)$.

A diasztolés kamrai falmerevséget számos faktor mellett leginkább a myocardium intra- és extracelluláris komponenseinek változásai befolyásolják (pl. fibrózis, ödéma) (16). A falmerevséget jellemző EDPVR-értékek esetében a két hipertrófia modell között nem találtunk különbséget (2. táblázat és 4. ábra). Ezen adatok öszszefüggést mutatnak az edző állatokban megfigyelhető kollagénlerakódás hiányával. Az AB-állatok esetében megfigyelhető kizárólag szubendokardiális fibrózis kevésbé lehet releváns ezen funkcionális paraméter befolyásolásában.

A verőmunka a BK egyetlen szívciklus alatti külső mechanikus munkája, mely a P-V-hurkok által bezárt terület nagyságából számítható ki (5. ábra és 2. táblázat). A PVA egyenesen arányos a myocardium energia-, tehát oxigénfogyasztásával (34). Míg a fiziológiás hipertrófia esetében a kontrollállatokkal megegyező energiafelhasználást figyeltünk meg, addig patológiás hipertrófiában annak értéke emelkedett volt (5. ábra). Ennek eredményeképpen a BK-teljesítmény mechanikus hatásfoka emelkedést mutatott sportszív esetében, míg patológiás szívizom-hipertrófia esetében változatlan maradt (5. ábra). Eredményeink utalhatnak a már korábban leírt metabolikus különbségekre a szívizom fiziológiás és patológiás állapotai között: az edzés következtében mind a glükóz- és zsírsavoxidáció mértéke megemelkedik, ezzel szemben patológiás hipertrófiában a glükózfelhasználás növekedését csökkenő zsírsavoxidáció kíséri (1).

A szív energiafelhasználásának fontos faktoraként a VAC jellemzi a BK és az artériás rendszer közötti kölcsönhatást az artériás elasztancia és a BK-i végszisztolés elasztancia arányaként (19). Az edzett állatok körében megfigyelt megnövekedett VAC a BK és az artériás rendszer közötti kedvezőbb kapcsolásra utal. A nyomás túlterheléssel összefüggő szívizom-hipertrófia esetében megfigyelhető változatlan VAC utalhat arra, hogy a BK megnövekedett szisztolés teljesítmé- nye kompenzálja a megnövekedett artériás terhelést (2. táblázat). Ezen megfigyeléseink összhangban állnak humán tanulmányok eredményeivel, amelyek a ventrikulo-arteriális kapcsolást vizsgálták sportolókban, és magasvérnyomás-betegséggel összefüggő BK-hipertrófiában szenvedő betegeken $(35,36)$.

A két hipertrófiatípus között jellegzetes különbségeket mutató paraméterek, mint az aktív relaxáció és a mechanikus hatásfok, energiafüggő mutatók. Ezért vizsgáltuk a mitokondriális transzkripciós koaktivátor PGC1a miokardiális expresszióját, amely a mitokondriális biogenezis és funkció szabályozásán keresztül a miokardiális energiafelhasználás egyik elsődleges regulátora (37). Korábbi szakirodalmi adatokkal összhangban (38), mind a PGC-1a, mind pedig koaktivátorai és célpontjai (ERR $\beta$, NRF1, PPARa, és CytC) esetében azok downregulálódását figyeltük meg, amely tükrözheti a patológiás hipertrófiában megfigyelhető mitokondriális diszfunkciót és az energiafelhasználás zsírsavról glükózra történő eltolódását (6. ábra D). A fiziológiás hipertrófiában a szívizomsejtek változatlan vagy megnövekedett mitokondriális biogenezise jellemző (38). Eredményeink alapján nem volt megfigyelhető ezen gének upregulációja a sportszív úszómodelljében (6. $D$ ábra). Ezen két hipertrófia modellünk közötti különbség mutathatja, hogy a mitokondriális biogenezis és funkció szabályozómolekuláinak gyógyszeres befolyásolása kulcsszerepet játszhat a patológiás hipertrófia kezelésében.

\section{Következtetések}

Kutatócsoportunk elsőként mutatta be a fiziológiás és kompenzált patológiás szívizom-hipertrófia részletes hemodinamikai összehasonlítását releváns patkány modelleken. Bár a hipertrófia mértéke hasonló nagyságú volt a két modell esetében, jellegzetes különbségeket találtunk a korai diasztolés funkció tekintetében: az aktív relaxáció kedvezőbbnek bizonyult fiziológiás hipertrófiában, míg annak markáns romlása volt megfigyelhető patológiás szívizom-megnagyobbodásban. A BK-i mechanoenergetikai paraméterek (mechanikus hatásfok és ventrikulo-arteriális kapcsolás) javulást mutattak a fizikai edzéssel összefüggő szívizom-hipertrófia esetében, míg változatlanok maradtak a nyomás-túlterhelés indukálta patológiás hipertrófiában. A mitokondriális funkciót és biogenezist jellemző miokardiális gének expressziós változása adhat magyarázatott ezen energiafüggő funkcionális eltérések tekintetében.

A munkát támogatta a Nemzeti Kutatási, Fejlesztési és Innovációs Hivatal (NVKP 16-1-2016-0017), a Nemzeti Fejlesztési Ügynökség (TÁMOP-4.2.2/B-10/1-2010-0013), az Országos Tudományos Kutatási Alapprogram (OTKA 1055555) és a Magyar Tudományos Akadémia Bolyai János Kutatási Ösztöndíja (R.T.). 


\section{Irodalom}

1. Bernardo BC, Weeks KL, Pretorius L, et al. Molecular distinction between physiological and pathological cardiac hypertrophy: experimental findings and therapeutic strategies. Pharmacol Ther 2010; 191-227. doi: 10.1016/j.pharmthera.2010.04.005

2. McMullen JR, Shioi T, Zhang L, et al. Phosphoinositide 3-kinase(p110alpha) plays a critical role for the induction of physiological, but not pathological, cardiac hypertrophy. Proc Natl Acad Sci U S A 2003; 12355-60. doi: 10.1073/pnas.1934654100

3. Ellison GM, Waring CD, Vicinanza C, et al. Physiological cardiac remodeling in response to endurance exercise training: cellular and molecular mechanisms. Heart 2012; 5-10. doi: 10.1136/heartj$\mathrm{nl}-2011-300639$

4. McMurray JJ, Pfeffer MA. Heart failure; Lancet 2005; 1877-89. doi: 10.1016/S0140-6736(05)66621-4

5. Shephard RJ, Balady GJ. Exercise as cardiovascular therapy. Circulation 1999; 963-72. doi: 10.1161/01.CIR.99.7.963

6. Thompson PD, Buchner D, Pina IL, et al. Exercise and physical activity in the prevention and treatment of atherosclerotic cardiovascular disease: a statement from the Council on Clinical Cardiology (Subcommittee on Exercise, Rehabilitation, and Prevention) and the Council on Nutrition, Physical Activity, and Metabolism (Subcommittee on Physical Activity). Circulation 2003; 3109-16. doi: 10.1161/01. CIR.0000075572.40158.77

7. McMullen JR, Jennings GL. Differences between pathological and physiological cardiac hypertrophy: novel therapeutic strategies to treat heart failure. Clin Exp Pharmacol Physiol 2007; 255-62. doi: 10.1111/j.1440-1681.2007.04585.x

8. Iemitsu M, Miyauchi T, Maeda S, et al. Physiological and pathological cardiac hypertrophy induce different molecular phenotypes in the rat. Am J Physiol Regul Integr Comp Physiol 2001; R2029-36. doi: 10.1152/ajpregu.2001.281.6.R2029

9. Weeks KL, McMullen JR. The athlete's heart vs. the failing heart: can signaling explain the two distinct outcomes? Physiology (Bethesda) 2011; 97-105. doi: 10.1152/physiol.00043.2010

10. Derumeaux G, Mulder P, Richard V, et al. Tissue Doppler imaging differentiates physiological from pathological pressure-overload left ventricular hypertrophy in rats. Circulation 2002; 1602-8. doi: 10.1161/01.CIR.0000012943.91101.D7

11. D'Andrea A, D'Andrea L, Caso P, et al. The usefulness of Doppler myocardial imaging in the study of the athlete's heart and in the differential diagnosis between physiological and pathological ventricular hypertrophy. Echocardiography 2006; 149-57. doi: 10.1111/j.15408175.2006.00186.x

12. Hildick-Smith DJ, Shapiro LM. Echocardiographic differentiation of pathological and physiological left ventricular hypertrophy. Heart 2001; 615-9. doi: 10.1136/heart.85.6.615

13. Georgakopoulos D, Kass DA. Estimation of parallel conductance by dual-frequency conductance catheter in mice. Am J Physiol Heart Circ Physiol 2000; H443-50. doi: 10.1152/ajpheart.2000.279.1.H443 14. Radovits $T$, Olah A, Lux A, et al. Rat model of exercise-induced cardiac hypertrophy: hemodynamic characterization using left ventricular pressure-volume analysis. Am J Physiol Heart Circ Physiol 2013; H124-34. doi: 10.1152/ajpheart.00108.2013

15. Nemeth BT, Matyas C, Olah A, et al. Cinaciguat prevents the development of pathologic hypertrophy in a rat model of left ventricular pressure overload. Sci Rep 2016; 37166. doi: 10.1038/srep37166 16. Pacher $P$, Nagayama $T$, Mukhopadhyay $P$, et al. Measurement of cardiac function using pressure-volume conductance catheter technique in mice and rats. Nat Protoc 2008; 1422-34. doi: 10.1038/ nprot. 2008.138

17. Kass DA. Clinical ventricular pathophysiology: a pressure-volume view. In: Wartlier DC, editor. Baltimore: Williams \& Wilkins; 1995. 18. Suga $H$. Cardiac energetics: from $E(\max )$ to pressure-volume area. Clin Exp Pharmacol Physiol 2003; 580-5. doi: 10.1046/j.14401681.2003.03879.x

19. Sunagawa K, Maughan WL, Burkhoff D, et al. Left ventricular interaction with arterial load studied in isolated canine ventricle. Am
J Physiol 1983; H773-80. doi: 10.1152/ajpheart.1983.245.5.H773

20. Frey N, Olson EN. Cardiac hypertrophy: the good, the bad, and the ugly. Annual Rev Physiol 2003; 45-79. doi: 10.1146/annurev.physiol.65.092101.142243

21. Wang $Y$, Wisloff $U$, Kemi OJ. Animal models in the study of exercise-induced cardiac hypertrophy. Physiol Res 2010; 633-44.

22. Wilkins BJ, Dai YS, Bueno OF, et al. Calcineurin/NFAT coupling participates in pathological, but not physiological, cardiac hypertrophy. Circ Res 2004; 110-8. doi: 10.1016/j.peptides.2010.04.026

23. Juric $D$, Wojciechowski $P$, Das DK, et al. Prevention of concentric hypertrophy and diastolic impairment in aortic-banded rats treated with resveratrol. Am J Physiol; Heart Circ Physiol 2007; H2138-43. doi: 10.1152/ajpheart.00852.2006

24. Scharhag J, Schneider G, Urhausen A, et al. Athlete's heart: right and left ventricular mass and function in male endurance athletes and untrained individuals determined by magnetic resonance imaging. J Am Coll Cardiol 2002; 1856-63. doi: 10.1016/S07351097(02)02478-6

25. Spirito P, Pelliccia A, Proschan MA, et al. Morphology of the "athlete's heart" assessed by echocardiography in 947 elite athletes representing 27 sports. Am J Cardiol 1994; 802-6. doi: 10.1016/00029149(94)90439-1

26. Kompa AR, Wang BH, Phrommintikul A, et al. Chronic urotensin II receptor antagonist treatment does not alter hypertrophy or fibrosis in a rat model of pressure-overload hypertrophy. Peptides 2010; 1523-30. doi: 10.1016/j.peptides.2010.04.026

27. Moens AL, Takimoto E, Tocchetti CG, et al. Reversal of cardiac hypertrophy and fibrosis from pressure overload by tetrahydrobiopterin: efficacy of recoupling nitric oxide synthase as a therapeutic strategy. Circulation 2008; 2626-36. doi: 10.1161/CIRCULATIONAHA.107.737031

28. Cingolani $\mathrm{OH}, \mathrm{Kass} \mathrm{DA}$. Pressure-volume relation analysis of mouse ventricular function. Am J Physiol Heart Circ Physiol 2011; H2198-206. doi: 10.1152/ajpheart.00781.2011

29. Chen $\mathrm{H}$, Hwang $\mathrm{H}$, McKee LA, et al. Temporal and morphological impact of pressure overload in transgenic FHC mice. Front Physiol 2013; 205. doi: 10.3389/fphys.2013.00205

30. Takimoto E, Champion HC, Li M, et al. Oxidant stress from nitric oxide synthase-3 uncoupling stimulates cardiac pathologic remodeling from chronic pressure load. J Clin Invest 2005; 1221-31. doi: $10.1172 / \mathrm{JCl} 21968$

31. Zhao W, Choi JH, Hong GR, et al. Left ventricular relaxation. Heart Fail Clin 2008; 37-46. doi: 10.1016/j.hfc.2007.12.001

32. Caselli S, Maron MS, Urbano-Moral JA, et al. Differentiating left ventricular hypertrophy in athletes from that in patients with hypertrophic cardiomyopathy. Am J Cardiol 2014; 1383-9. doi: 10.1016/j. amjcard.2014.07.070

33. Kovacs A, Apor A, Nagy A, et al. Left ventricular untwisting in athlete's heart: key role in early diastolic filling? Int J Sports Med 2014; 259-64. doi: 10.1055/s-0033-1349076

34. Suga $H$, Hayashi $T$, Shirahata M. Ventricular systolic pressure-volume area as predictor of cardiac oxygen consumption. Am J Physiol 1981; H39-44. doi: 10.1152/ajpheart.1981.240.1.H39

35. Florescu M, Stoicescu C, Magda S, et al. "Supranormal" cardiac function in athletes related to better arterial and endothelial function. Echocardiography 2010; 659-67. doi: 10.1111/j.15408175.2009.01121.x

36. Nitenberg A, Loiseau A, Antony I. Left ventricular mechanical efficiency in hypertensive patients with and without increased myocardial mass and with normal pump function. Am J Hypertens 2001; 1231-8. doi: 10.1016/S0895-7061(01)02205-1

37. Finck BN, Kelly DP. Peroxisome proliferator-activated receptor gamma coactivator-1 (PGC-1) regulatory cascade in cardiac physiology and disease. Circulation 2007; 2540-8. doi: 10.1161/CIRCULATIONAHA.107.670588

38. Rimbaud S, Garnier A, Ventura-Clapier R. Mitochondrial biogenesis in cardiac pathophysiology. Pharmacol Rep 2009; 131-8. doi: 10.1016/S1734-1140(09)70015-5 